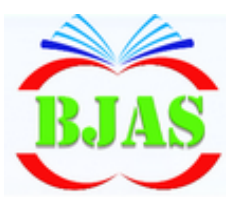

Available online at http://journal.bajas.edu.iq

College of Agriculture, University of Basrah

DOi:10.21276/basjas

ISSN 1814 - 5868

Basrah J. Agric. Sci., 32(Spec Issue): 124-134, 2019

\section{Basrah \\ Journal of \\ Agricultural \\ Sciences}

E-ISSN: 2520-0860

\title{
Effect of Spraying with Seaweed Extract on Growth and Yield of Two Varieties of Wheat (Triticum aestivum $\mathbf{L}$.)
}

\author{
Ali R. K.Al-Hasany ${ }^{1 *}$, Mohammed A.R. Aljaberi ${ }^{1}$ \& Sundus K.J. Alhilfi ${ }^{2}$ \\ ${ }^{1}$ Department of Field Crops, College of Agriculture, University of Al-Muthanna, Iraq \\ ${ }^{2}$ Department of Field Crops, College of Agriculture, University of Basrah, Iraq \\ *Corresponding author e-mail: ali_rheem2002@yahoo.com
}

Received 20 April 2019; Accepted 18 June 2019; Available online 18 September 2019

\begin{abstract}
A field experiment was conducted in agricultural field in Al-Rumaitha, district $25 \mathrm{~km}$ north of Al-Muthanna city, during the agricultural season 2017/2018. The aim was to study the effect of spray of seaweed extract at 0,1 and 2 g. $1^{-1}$ on growth and yield of two varieties of wheat (Bhooth 22 and Eebaa 99). The experiment was applied according to split plot design with three replicates. The results showed that the increasing of the concentration of seaweed extract up to $2 \mathrm{~g} \mathrm{~L}^{-1}$ in spray solution led to increase some growth properties (plant height, leaf chlorophyll concentration, flag leaf area and spike length). In addition seaweed extract up to $2 \mathrm{~g}^{-1} \mathrm{l}^{-1}$ lead to increase the number of spikes $/ \mathrm{m}^{2}$, grain yield, and biological yield gave $31.85 \%, 39.05 \%$ and $39.79 \%$ respectively compared to the control treatment, while the concentration of seaweed extract up to $1 \mathrm{~g} . \mathrm{l}^{-1}$ lead to increased 1 the number of grains per spike. The results revealed a difference in between the varieties in almost growth and reproductive traits. Bhooth 22 has the highest plant height, leaf chlorophyll concentration, spike length, and number of spikes/ $\mathrm{m}^{2}$, grain yield $\left(5979 \mathrm{~kg} \mathrm{ha}^{-1}\right)$ and total biomass yield was and the highest biomass $\left(13571 \mathrm{~kg} \mathrm{ha}^{-1}\right)$. The interaction between spraying of seaweed extract and varieties explained a significant effect on leaf chlorophyll concertation and biomass yield.
\end{abstract}

Keywords: Seaweed, Varieties, Triticum aestivum L..

\section{Introduction}

Wheat Triticum aestivum L. is the third largest crop production in the world after corn and rice, and an essential source of calories in human, wheat comes at the second stage after rice as a main food crop; given more extensive use of maize as animal feed. Wheat is grown across a wide range of environments and is considered to have the broadest adapt- tation of all cereal crop species conditions and that permits large-scale cultivation and longterm storage. Currently, about $65 \%$ of the wheat crop is used for food, $17 \%$ for animal feed, and $12 \%$ in industrial applications, including biofuel. It provides for an adult person more than $50 \%$ of his energy needs and $25 \%$ of protein as well as contain 
vitamins, amino acids and some mineral salts (Saudi, 2013).

One of the modern ways to grow and develop crops is to provide them with the nutrients, such as use of some organic compounds. This compound found naturally in the plant, including seaweed extracts, which is a common fertilizer used in recent times as a good source of nutrients and major and micro-growth regulators. When they spray on the plant, they increase the ability of the roots to grow, and absorb the nutrients. In addition, increase the thickness and strength of the stem as well as increase the leaf area and thus increase the root and vegetative growth (Babilie et al., 2015).

In one hand, the global trend is now towards decreasing the use of chemical fertilizers in order to maintain environmental health and reduce the pollution. In other hand, the use of natural compounds in plants nutrition increased in term of organic agriculture, which characterized by low toxicity, non-polluting environment, and cheap cost and have no harmful effects (Zodape et al., 2010). In addition, the applying of seaweed extract promotes growth, delays leaves senescence and increases the strength of the plant because it is contain nutrients, growth regulators and some amino acids, which increases the plant's ability to absorb nutrients and increase disease resistance, which leads to increased productivity and improved quality (Spinelli et al., 2010).

The success of planting of any crop depends on optimal management, effective field methods, and abundance of growth factors, especially those suitable for the environment and their adaptability to local conditions. Varieties differ in growth, production, and their response to environmental conditions depending on their genetic susceptibility. (Riaz et al., 2010). Thus, this experiment was carried out with the aim of identifying the response of two varieties of wheat to spraying with different concentrations of seaweed extract.

\section{Materials \& Methods}

A field experiment was conducted in one of the agricultural fields of Al-Rumaitha district $25 \mathrm{~km}$ north of Al-Muthanna province during the agricultural season $2017 / 2018$ to study the effect of spraying with seaweed extract on the growth and yield of two varieties of wheat. The experiment was applied according to the design of randomized completely blocks design (R.C.B.D). The first factor included spraying with three concentrations of seaweed extract $\left(0,1\right.$ and 2 g. $\left.^{-1}\right)$, which they are symbolized S0, S1 and S2. The second factor were two varieties of wheat Bhooth22 and IPA-99 which they are symbolized by V1 and V2. Characteristic of experimental soil were shown (Table 1).

The field of study was plowed before sowing; plowed soil was pulverized by rotavator and the soil was leveled the soil was divided according to the design used then after, the seeds were planted in 15 November. Nitrogen fertilization applied with $120 \mathrm{~kg}$ N.ha ${ }^{-1}$ (as urea $46 \% \mathrm{~N}$, phosphorus at $80 \mathrm{~kg}$ P2O5 ha ${ }^{-1}(46 \% \quad$ P) (Abidi, 2011). Experimental unit $\left(2 \times 2=4 \mathrm{~m}^{2}\right)$ the distance between the rows $20 \mathrm{~cm}$. The Acadian Seaweed Extract company, produced by Canada's Acadiansea plants Company, carried out the spray; the components are shown in table (2). The seaweed extract solutions has been spired on plants in three times, the first in the elongation phase, the second after 20 days from the first and the third after three days from the second time. The spraying process was apply in the 
Al-Hasany et al. / Basrah J. Agric. Sci., 32 (Special Issue): 124-133, 2019

morning or evening to avoid high temperature. A cleaning solution was added to the spray solution to reduce the surface tension of the water and to ensure the complete wetness of the leaves in order to increase the efficiency of the spray solution. The data were statistically analyzed according to the design used in the statistical program
(GenStat12) and the statistical averages were compared according to the L.S.D test under the probability level of 5\% (Al-Rawi \& Khalaf Allah, 2000).

Random samples of field soil were taken from depth of 0-30 cm. To measure some of physical and chemical traits of field soil (Table 2).

Table (1): Some physical and chemical characteristics of the soil before planting

\begin{tabular}{|c|c|c|c|}
\hline Attribute & & Value & Unit \\
\hline $\mathrm{pH}$ & & 7.3 & - \\
\hline E.C & & 3.8 & ds. $m^{-1}$ \\
\hline CEC & & 20.6 & 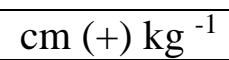 \\
\hline Nitrogen Ready & & 18 & $\mathrm{mg} \mathrm{kg}^{-1}$ soil \\
\hline Phosphorus Ready & & 8.5 & $\mathrm{mg} \mathrm{kg}^{-1}$ soil \\
\hline Potassium ready & & 155 & $\mathrm{mg} \mathrm{kg}^{-1}$ soil \\
\hline \multirow{3}{*}{ Analysis of minute volumes } & sand & 240 & \multirow{3}{*}{$\mathrm{g} \mathrm{kg}^{-1}$} \\
\hline & silt & 440 & \\
\hline & Clay & 320 & \\
\hline Tissue & & Clay loam & \\
\hline
\end{tabular}

Table (2): Acadian fertilizer components containing seaweed extract.

\begin{tabular}{cc}
\hline The ingredients & Content \\
\hline Sea-Weeds & $50 \%$ \\
\hline NPK, Metal \& Ashes & $40 \%$ \\
\hline Amino acids & $4 \%$ \\
\hline Agnic acid & $5-10 \%$ \\
\hline Manitol & $4 \%$ \\
\hline Vitamins of B group & $(0.7,0.065)$ \\
B1,B2 & $\mathrm{ppm}$ \\
\hline
\end{tabular}

\section{Results \& Discussion}

\section{1- Plant height (cm)}

The results of table (3) indicated a significant effect for seaweed extract in plant high. The highest concentration S2 gave the highest mean of plant height $(82.07 \mathrm{~cm})$ the concentration $\mathrm{S} 1$ that gave $79.53 \mathrm{~cm}$. While S0 treatment gave, the lowest average of this value $76.92 \mathrm{~cm}$ (Table 3). The content of seaweed extract of macro and micronutrients and plant growth regulators (Table 2), which contribute to increasing the growth of the plant in general, which reflected the increase in plant height, This result is similar with what Mohammad found in his study (Mohammad, 2013). The plant high increase with the increase of spraying concentrations of seaweed extract.

The results of table (3) revealed a significant difference in between the verities in plant high. The cultivar Bhooth22 (V1) gave the highest mean of plant height, which reached $80.48 \mathrm{~cm}$ as compared to IPA-99 (V2), which gave the lowest mean of plant height $78.73 \mathrm{~cm}$. Previous results have been found by Ali \& Hamza (2013) and Al- Yasiri \& Al-Samak (2015), that is the cultivars vary in plant height. The results of the interaction between the seaweed extract and the varieties, revealed no significant differences in plant height (Table 3 ). 
Al-Hasany et al. / Basrah J. Agric. Sci., 32 (Special Issue): 124-133, 2019

Table (3): Effect of seaweed extract, varieties and their interaction in plant height (cm).

\begin{tabular}{ccccc}
\hline Varieties (V) & \multicolumn{3}{c}{ Seaweeds $(\mathrm{S})$} & \multirow{2}{*}{$\begin{array}{c}\text { Varieties } \\
\text { average }\end{array}$} \\
\cline { 2 - 4 } & $\mathrm{S}_{0}$ & $\mathrm{~S}_{1}$ & $\mathrm{~S}_{2}$ & \\
\hline $\mathrm{V}_{1}$ & 77.57 & 80.40 & 83.47 & 80.48 \\
\hline $\mathrm{V}_{2}$ & 76.27 & 79.27 & 80.67 & 78.73 \\
\hline Seaweeds average & 76.92 & 79.83 & 82.07 & \\
\hline L.S.D 0.05 & $\mathrm{~V}$ & $\mathrm{~S}$ & & $\mathrm{~V} \times \mathrm{S}$ \\
\hline
\end{tabular}

2- The content of the leaves of chlorophyll (SPAD)

The results table (4) displayed a significant effect for seaweed extract in the chlorophyll content in the leaves the highest concentration S2 gave the highest mean was 31.47 SPAD, with an increase of $15 \%$ from concentration S1 which gave an average of 27.33 SPAD (18\%) from the control S0, which gave the lowest average chlorophyll content in the leaves was 23.17 SPAD. This increase in leaf content of chlorophyll, the elements in the extract have a role in activity of many important enzymes, especially responsible enzymes for the formation and construction of chlorophyll molecule, which contributed to the increase in content in the leaves, and this result agreed with what reached (Kasim et al., 2015).

The results of table (4) revealed a significant difference in the varieties in chlorophyll content of the leaves. Bhooth22 (V1) gave the highest mean of the chlorophyll content of the leaves was 29.07 SPAD, while the IPA-99 (V2) gave the lowest average 25.58 SPAD. this results agreed with (Rekani et al., 2017). The interaction treatment (V1 $\times$ S2) was the highest 34.47 SPAD, while the plants of IPA-99 (V2) gave with the control treatment of extract $(\mathrm{V} 2 \times \mathrm{S} 0)$ was 22.27 SPAD (Table 4).

Table (4): Effect of seaweed extract, varieties and their interaction in chlorophyll content (SPAD).

\begin{tabular}{|c|c|c|c|c|}
\hline Varieties & \multicolumn{3}{|c|}{ Seaweeds (S ) } & \multirow{2}{*}{$\begin{array}{l}\text { Varietie } \\
\text { average }\end{array}$} \\
\hline Varieties (V) & $\mathrm{S}_{0}$ & $\mathrm{~S}_{1}$ & $\mathrm{~S}_{2}$ & \\
\hline $\mathrm{V}_{1}$ & 24.07 & 28.67 & 34.47 & 29.07 \\
\hline $\mathrm{V}_{2}$ & 22.27 & 26.00 & 28.47 & 25.58 \\
\hline Seaweeds average & 23.17 & 27.33 & 31.47 & \\
\hline \multirow[t]{2}{*}{ L.S.D 0.05} & V & $S$ & \multicolumn{2}{|c|}{$\mathrm{V} \times \mathrm{S}$} \\
\hline & 1.21 & 1.49 & \multicolumn{2}{|c|}{2.11} \\
\hline
\end{tabular}


Al-Hasany et al. / Basrah J. Agric. Sci., 32 (Special Issue): 124-133, 2019

\section{3- Flag leaf area $\left(\mathrm{cm}^{2}\right)$}

The results table (5) presented a significant effect for seaweed extract in the area of the flag leaf. The highest concentration S2 gave the highest mean was $2680 \mathrm{~cm}^{2}$, and significantly, higher than the second concentration of S1 which gave an average of $24.04 \mathrm{~cm}^{2}$, which was significantly higher than the S0. The role of marine extracts in increasing the activity of many enzymes involved in phylogenetic processes as well as their role in increasing photosynthesis, which contributes to the increase of the products of this process and to better growth leading to increase the area of the flag leaf (Shahbazi et al., 2015).

In case of varieties and interaction between the seaweed extract and the varieties, no significant differences were found (Table 5).

Table (5): Effect of spraying with seaweed extract and varieties and interaction between them in the area of flag leaf $(\mathrm{cm})$.

\begin{tabular}{|c|c|c|c|c|}
\hline rieties & \multicolumn{3}{|c|}{ Seaweeds (S) } & \multirow{2}{*}{$\begin{array}{l}\text { Varieties } \\
\text { average }\end{array}$} \\
\hline Varieties (V) & $\mathrm{S}_{0}$ & $\mathrm{~S}_{1}$ & $\mathrm{~S}_{2}$ & \\
\hline $\mathrm{V}_{1}$ & 19.83 & 23.66 & 26.71 & 23.40 \\
\hline $\mathrm{V}_{2}$ & 20.61 & 24.42 & 26.89 & 23.97 \\
\hline Seaweeds average & 20.20 & 24.04 & 26.80 & \\
\hline \multirow[t]{2}{*}{ L.S.D 0.05} & $\mathrm{~V}$ & $\mathrm{~S}$ & \multicolumn{2}{|c|}{$\mathrm{V} \times \mathrm{S}$} \\
\hline & N.S & 1.21 & \multicolumn{2}{|c|}{ N.S } \\
\hline \multicolumn{5}{|c|}{$\begin{array}{l}\text { Table (6): Effect of spraying with seaweed extract and varieties and thei } \\
\text { overlap in the number of spike }\left(\mathbf{m}^{2}\right) .\end{array}$} \\
\hline & \multicolumn{3}{|c|}{ Seaweeds (S ) } & \multirow{2}{*}{$\begin{array}{l}\text { Varieties } \\
\text { average }\end{array}$} \\
\hline Varieties (V) & $\mathrm{S}_{0}$ & $\mathrm{~S}_{1}$ & $\mathrm{~S}_{2}$ & \\
\hline $\mathrm{V}_{1}$ & 363.30 & 421.70 & 466.70 & 417.20 \\
\hline $\mathrm{V}_{2}$ & 316.70 & 395.00 & 430.00 & 380.60 \\
\hline Seaweeds average & 340.00 & 408.30 & 448.30 & \\
\hline \multirow[t]{2}{*}{ L.S.D 0.05} & V & S & \multicolumn{2}{|c|}{$\mathrm{V} \times \mathrm{S}$} \\
\hline & 27.62 & 33.83 & \multicolumn{2}{|c|}{ N.S } \\
\hline
\end{tabular}


Table (7) Effect of spraying with seaweed extract and varieties and their interaction between them in the number of grains in spike.

\begin{tabular}{|c|c|c|c|c|}
\hline Varieties & \multicolumn{3}{|c|}{ Seaweeds (S ) } & \multirow{2}{*}{$\begin{array}{l}\text { Varieties } \\
\text { average }\end{array}$} \\
\hline Varieties (V) & $\mathrm{S}_{0}$ & $\mathrm{~S}_{1}$ & $\mathrm{~S}_{2}$ & \\
\hline $\mathrm{V}_{1}$ & 52.9 & 59.3 & 62.3 & 58.2 \\
\hline $\mathrm{V}_{2}$ & 55.50 & 68.50 & 63.50 & 62.50 \\
\hline Seaweeds average & 54.20 & 63.90 & 62.90 & \\
\hline \multirow[t]{2}{*}{ L.S.D 0.05} & V & S & \multicolumn{2}{|c|}{$\mathrm{V} \times \mathrm{S}$} \\
\hline & N.S & 7.97 & \multicolumn{2}{|c|}{ N.S } \\
\hline
\end{tabular}

\section{4- Number of spike $\left(\mathrm{m}^{2}\right)$}

The results of table (6) indicated that there was a significant increase in the number of spike $\mathrm{m}^{2}$ when increasing the concentrations of seaweed extract in the spray solution. The $\mathrm{S} 1$ gave the highest number of spike $\left(\mathrm{m}^{2}\right)$ 448.30 spike $\mathrm{m}^{2}$, an increase of $10 \%$ from the second concentration which increased by $20 \%$ control treatment, which gave the number of spike was 340.00 spike $\mathrm{m}^{2}$, this result was agreed with what found by (Kavitha et al., 2008).

The results of table (6) revealed a significant difference in between the varieties in the number of spikes $\mathrm{m}^{2}$. Bhooth22 (V1) gave an average of 417.20 spike $\mathrm{m}^{2}$ and an increased rate of $10 \%$ for IPA-99 (V2), which gave the lowest number of spike 380.60 spike $\mathrm{m}^{2}$, may due to genetic variation among species, this result was agreed with $\mathrm{Al}$ Jumelly (2011) and Al-Asseel et al. (2018) who pointed out the difference in wheat varieties between them in the number of spikes $\mathrm{m}^{2}$.

\section{5 - The number of seeds in the spike (Spike} ha-1)

The results in table (7) explained the seaweed extract $\mathrm{S} 1$ gave the number of seeds in spike, which was 63.90-spike. $\mathrm{ha}^{-1}$, which did not differ significantly from the $\mathrm{S} 2$ concentration, which gave an average of 62.90 spike. $\mathrm{ha}^{-1}$ seeds, while the control treatment (non-spray S0), gave the lowest average of this feature was 54.20 spike $\mathrm{ha}^{-1}$. These results were consistent with what was indicated by (Abdul-Jabar et al., 2012).

There were no significant differences between the varieties and the interaction between the seaweed extract and the varieties in the number of seeds in spike (Table 7).

\section{6- Weight of 1000 grain (g):}

The results of table (8) indicated a significant increase in the weight of 1000 grain, the treatment S0 gave the highest mean of 36.87 $\mathrm{g}$, while $\mathrm{S} 2$ gave a mean average of $32.32 \mathrm{~g}$. The decrease may be due to the increase of the extract concentrations. This resulted in a 
Al-Hasany et al. / Basrah J. Agric. Sci., 32 (Special Issue): 124-133, 2019

decrease in the number of grains deposited in a single pill and then decreased in weight. However, this decrease was compensated within the spike due to the increase in the number of grains (Table 8). This result differed as indicated by Mohammad (2013).

The results showed in table (8) that, Bhooth22 (V1) significantly increased in the weight of 1000 seeds that gave the highest average of $36.47 \mathrm{~g}$ while the IPA-99 (V2) gave $33.27 \mathrm{~g}$. These results agreed with the conclusion of Al-Hassan et al. (2013) and
Ziydan et al. (2018) that indicated that the varieties differ among themselves in the weight of 1000 grains for wheat.

\section{7- Grain yield (kg. ha-1)}

According to table (9), there was a significant increase in grain yield with a higher concentration of the extract solution. The highest concentration S2 recorded the highest grain yield of $6501 \mathrm{~kg}$. ha ${ }^{-1}$ while the control treatment of $\mathrm{S} 0$ gave the lowest mean of 4674 $\mathrm{kg}$. $\mathrm{ha}^{-1}$. According to the results in table (7) the number of grains in spike (table 8),

Table (8): Effect of spraying with seaweed extract and varieties and their overlap in the weight of 1000 grains (g).

\begin{tabular}{|c|c|c|c|c|}
\hline Sarieties & \multicolumn{3}{|c|}{ Seaweeds (S ) } & \multirow{2}{*}{$\begin{array}{l}\text { Varieties } \\
\text { average }\end{array}$} \\
\hline Varieties (V) & $\mathrm{S}_{0}$ & $\mathrm{~S}_{1}$ & $\mathrm{~S}_{2}$ & \\
\hline $\mathrm{V}_{1}$ & 38.33 & 36.87 & 34.17 & 36.47 \\
\hline $\mathrm{V}_{2}$ & 35.40 & 33.93 & 30.47 & 33.27 \\
\hline Seaweeds average & 36.87 & 35.40 & 32.32 & \\
\hline \multirow[t]{2}{*}{ L.S.D 0.05} & V & $S$ & \multicolumn{2}{|c|}{$\mathrm{V} \times \mathrm{S}$} \\
\hline & 1.12 & 1.38 & \multicolumn{2}{|c|}{ N.S } \\
\hline \multicolumn{5}{|c|}{$\begin{array}{l}\text { Table (9): Effect of spraying with seaweed extract and varieties } \\
\text { and their overlap in grain yield }\left(\mathrm{kg}^{\left.-\mathrm{ha}^{-1}\right)} \text {. }\right.\end{array}$} \\
\hline & \multicolumn{3}{|c|}{ Seaweeds (S ) } & \multirow{2}{*}{$\begin{array}{l}\text { Varieties } \\
\text { Average }\end{array}$} \\
\hline Varieties (V) & $\mathrm{S}_{0}$ & $\mathrm{~S}_{1}$ & $\mathrm{~S}_{2}$ & \\
\hline $\mathrm{V}_{1}$ & 5112 & 5953 & 6873 & 5979 \\
\hline $\mathrm{V}_{2}$ & 4236 & 5293 & 6128 & 5219 \\
\hline Seaweeds average & 4674 & 5623 & 6501 & \\
\hline \multirow[t]{2}{*}{ L.S.D 0.05} & $\mathrm{~V}$ & $\mathrm{~S}$ & \multicolumn{2}{|c|}{$\mathrm{V} \times \mathrm{S}$} \\
\hline & 391.90 & 480.00 & \multicolumn{2}{|c|}{ N.S } \\
\hline
\end{tabular}


which contributed to the increase in grain yield. This result was consistent with what was obtained by Shahbazi et al. (2015).

The results of table (9) exhibited that Bhooth22 (V1) was significantly higher in the grain yield, which gave the highest mean of $5979 \mathrm{~kg}^{-1}$. While IPA-99 (V2) gave $5219 \mathrm{~kg}^{-1}$. these results agreed with the conclusion of AlHaydary (2009) and El- Zangana \& Sediq (2019).

There were no significant differences found between the extract and the varieties in Grain yield (Table 9).

\section{8- Biological yield: (kg. ha-1)}

The results of table (10) showed a significant increase of seaweed extract in the biological yield, the highest concentration S2 gave the highest biological yield of $14777 \mathrm{~kg} \cdot \mathrm{ha}^{-1}$ while the non-spray treatment S0 gave the lowest mean of $10567 \mathrm{~kg} \cdot \mathrm{ha}^{-1}$ (table 5). depended to table (5) this may be due to the grain yield in table (9), which was positively reflected in the increase in biomass. These results were consistent with what found by Kasim et al. (2015).

The results of table (10) revealed that (V1) recorded the highest mean of the biological value was $13574 \mathrm{~kg} \cdot \mathrm{ha}^{-1}$ which increased by 5\% than the IPA-99 (V2), which gave the lowest average of this feature was 11786 kg.ha ${ }^{-1}$. The superiority of cultivar (V1) in plant height and grain yield (Table $3 \& 9$ ), which contributed to the increase of biological, this result was agreed with Hussain et al. (2017). The V1 cultivar, which was sprayed with the highest concentration of extract S2 $(\mathrm{V} 1 \times \mathrm{S} 2)$, gave the highest mean yield $16262 \mathrm{~kg}$ ha-1, while the V2 cultivar were given with the control treatment of the extract S0. In addition (V2 $\times$ S0) gave the lowest biological yield was $10050 \mathrm{~kg} \cdot \mathrm{ha}^{-1}$ (Table 10).

Table (10): Effect of spraying with seaweed extract and varieties and their overlap in the biological yield (kg ha-1).

\begin{tabular}{|c|c|c|c|c|}
\hline Varieties & \multicolumn{3}{|c|}{ Seaweeds (S ) } & \multirow{2}{*}{$\begin{array}{l}\text { Varieties } \\
\text { average }\end{array}$} \\
\hline Varieties (V) & $\mathrm{S}_{0}$ & $\mathrm{~S}_{1}$ & $\mathrm{~S}_{2}$ & \\
\hline $\mathrm{V}_{1}$ & 11083 & 13367 & 16262 & 13571 \\
\hline $\mathrm{V}_{2}$ & 10050 & 12023 & 13283 & 11786 \\
\hline Seaweeds average & 10567 & 12695 & 14772 & \\
\hline \multirow[t]{2}{*}{ L.S.D 0.05} & $\mathrm{~V}$ & S & \multicolumn{2}{|c|}{$\mathrm{V} \times \mathrm{S}$} \\
\hline & 598.30 & 732.70 & \multicolumn{2}{|c|}{1036.20} \\
\hline
\end{tabular}




\section{Conclusions}

1- The increasing of the concentration of seaweed extract up to 2 g. $1^{-1}$ in spray solution led to increasing some growth properties (plant height, leaf content of chlorophyll, area of flag leaf and spike length).

2- Seaweed extract up to 2 g.1 ${ }^{-1}$ leads to increase the number of spikes $/ \mathrm{m} 2$, grain yield, and biological yield and gave $31.85 \%$, $39.05 \%$ and $39.79 \%$ respectively compared to the control. Treatment.

3- Seaweed extract up to 1 g. ${ }^{-1}$ leads to increased 1 the number of grains per spike.

4- The results revealed a difference between the varieties. Bhooth 22 has the highest plant height, leaf content of chlorophyll, spike length, number of spikes. $\mathrm{m}^{-2}$, grain yield $\left(5979 \mathrm{~kg} \mathrm{~h}^{-1}\right.$ ), total biomass yield and the highest biomass $\left(13571 \mathrm{~kg} \mathrm{~h}^{-1}\right)$.

5- The interaction between the spraying of seaweed extract and cultivars showed a significant effect on leaf chlorophyll content and biomass yield.

\section{Acknowledgements}

I would like to thank Dr. Ali Hleel Noaema from Department of Plant Production, College of Agriculture, University of Almuthanna, Iraq, for his valuable assistance with this research.

\section{References}

Abdul-Jabar, A.S; Al-Rashedy, H.S. \& AlUbeidi, M.A. (2012). Effect of the different seaweed extract (Seamino) concentrations on growth and seed chemical composition of two wheat varieties. J. Sci. Rafidain, 1(23): 100-113.

Abidi, J.A. (2011). Directory of chemical and organic fertilizers in iraq. General
Authority for Extension and Agricultural Cooperation -Ministry of Agriculture, Iraq: 86pp.

Al-Yasiri, A.S.M.M. \& Al-Samak, Q.H. (2015). Effect the foliar application of potassium in the growth yield five varieties of wheat Triticum aestivum L. Univ. Karbala J., 13(3): 105-114.

Al-Hassan, M.F.H., Jaddoa, K.A., Saudi, A.H. (2014). Respons to several varieties of wheat news (Triticum aestivum L.) rates for different seed. Thi-Qar J. Agric. Sci., 1(3): 143-165.

Al-Haydary, H. K.M. (2009). Wheat cultivars performance as effected by row spacing. Iraqi J. Agric. Sci., 40 (2): 66-78.

Al-Asseel, A.S.M.; Madb, D.S. \& AlKathee, M.H. (2018). Response of bread wheat (Triticum aestivum L.) cultivars for sowing dates. Tikrit Univ. J. Agric. Sci., 18(2): 4153.

Al Jumelly, I.A.S., (2011). Effect of foliar application of micronutrient levels spraying on growth and yield of three wheat varieties. Anbar Agric. Sci., 2(9): 113-121.

Al-Rawi, K.M. \& Khalaf Allah A.M. (2000). Design and Analysis of Agricultural Experiments. Dar Al Kutub Prin. \& Pub. Univ. Mosul. Min. High. Educ. Sci. Res.. Rep. Iraq: 213pp.

Ali, A.H. \& Hamza, H.R., (2013). Effect different planting patterns in groeth and yield of four bread wheat cultivars. Al Furat J. of Agric. Sci. .5(4): 94-103.

Babilie, R.; Abu Trabi, B.; Jbour, M. \& Murshed, R. (2015). Response of onion to foliar spray with seaweed extract and GA 
at different irrigation levels. Damascus Univ. J. Agric. Sci., 31(1): 159-169.

El-Zangana, D.D. \& Sediq, F.A.Q., (2019). Effect of spray durations by amino acids on the goodness and bread traits of varieties from bread wheat (Triticum aestivum L.). $3^{\text {rd }}$ Int. Sci. Conf. Agric. Sci.: 859-870.

Hussain, M.A; Dohuki, M.S. \& Ameen, H.A. (2017). Response of some bread wheat (Triticum aestivum L.) cultivars to nitrogen levels. Kufa J. Agric. Sci., 9(4): 365-390.

Kasim, W.A.; Hamada, E.A.M.; El-Din, N.G.S. \& Eskander, S.K. (2015). Influence of seaweed extracts on the growth, some metabolic activities and yield of wheat grown under drought stress. Int. J. Agron. Agric. Res. (IJAAR), 7(2): 173-189.

Mohammad, A.M.A. (2013). The effect of using different concentration of soluamine and $\mathrm{NaCl}$ on the growth and yield components of two kinds wheat (Triticum aestivum L.). J. Res. Coll. Basic Educ., 12(2): 703-723.

Rekani, O.A.O.; Dohuk, M.S.S. \& Hussain, M.A. (2017). Effect of phosphate fertilizer on growth and yield of five cultivars bread wheat. Iraqi J. Agric. Sci., 48(6): -1796 1804.

Saudi, A.H. (2013). Effect of temperature degree on germination and seedling characters of seeds of four wheat (Triticum aestivum L.) cultivars. Thi-Qar Univ. J. Agric. Res., 2(1): 81-99.

Shahbazi, F.; Nejad, M.S.; Salimi, A. \& Gilani, A. (2015). Effect of seaweed extracts on the growth and biochemical constituents of wheat. Int. J. Agri. Crop Sci., 8(3): 283-287.

Spinelli, F.; Fiori, G.; Noferini, M.; Sprocatti, M. \& Costa, G. (2010). A novel type of seaweed extract as a natural alternative to the use of iron chelates in strawberry production. Sci. Hortic., 12(5): 263-269.

Ziydan, B.A.; Muslih, A.F. \& Almehemdi, A.F. (2018). Effect of tillage systems on growth and yield of five cultivars of bread wheat. Iraqi J. Des. Stud., 8(1): 10-15.

Zodape, S.T.; Mukhopadhyay, S. ; Eswaran, K.; Reddy, M. \& Chikara, J. (2010). Enhanced yield and nutritional quality in green gram (Phaseolus radiatus L.) treated with seaweed extract. J. Sci. Ind. Res., 69: 468-471. 